\title{
Increased OPRMI DNA Methylation in Lymphocytes of Methadone-Maintained Former Heroin Addicts
}

\author{
David A Nielsen*,', Vadim Yuferov', Sara Hamon², Colin Jackson', Ann Ho', Jurg Ott ${ }^{2,3}$ and \\ Mary Jeanne Kreek' \\ 'Laboratory of the Biology of the Addictive Diseases, The Rockefeller University, New York, NY, USA; ${ }^{2}$ Laboratory of Statistical Genetics, \\ The Rockefeller University, New York, NY, USA; ${ }^{3}$ Beijing Institute of Genomics, Chinese Academy of Sciences, Beijing, China
}

\begin{abstract}
The $\mu$-opioid receptor is the site of action of opiates and opioids. We examined whether there are differences in cytosine:guanine (CpG) dinucleotide methylation in the OPRMI promoter between former heroin addicts and controls. We analyzed methylation at 16 CpG dinucleotides in DNA obtained from lymphocytes of 194 Caucasian former severe heroin addicts stabilized in methadone maintenance treatment and 135 Caucasian control subjects. Direct sequencing of bisulfite-treated DNA showed that the percent methylation at two CpG sites was significantly associated with heroin addiction. The level of methylation at the - 18 CpG site was $25.4 \%$ in the stabilized methadonemaintained former heroin addicts and $21.4 \%$ in controls $(p=0.0035$, generalized estimating equations (GEE); $p=0.0077$, t-test; false discovery rate $(F D R)=0.048)$, and the level of methylation at the $+84 \mathrm{CpG}$ dinucleotide site was $7.4 \%$ in cases and $5.6 \%$ in controls ( $p=0.0095$, GEE; $p=0.0067$, t-test; FDR $=0.080$ ). Both the -18 and the $+84 \mathrm{CpG}$ sites are located in potential SpI transcription factor-binding sites. Methylation of these CpG sites may lead to reduced OPRM I expression in the lymphocytes of these former heroin addicts. Neuropsychopharmacology (2009) 34, 867-873; doi: I0.1038/npp.2008. I08; published online 23 July 2008
\end{abstract}

Keywords: methylation; addiction; gene; heroin; methadone; CpG

\section{INTRODUCTION}

Chronic heroin use disrupts multiple physiological systems, contributing to addiction and relapse. Vulnerability to develop heroin addiction is due to drug-induced and environmental factors, as well as genetic factors (Kreek et al, 2005). Among the nongenetic factors may be integrated epigenetic factors including DNA methylation.

Cytosine methylation in genomic DNA is a common epigenetic mechanism, which occurs through the addition of a methyl group by DNA methyltransferases to cytosine residues in cytosine: guanine $(\mathrm{CpG})$ dinucleotides. $\mathrm{CpG}$ dinucleotides are often localized in clusters referred to as 'CpG islands' (Antequera and Bird, 1993). There are approximately $45000 \mathrm{CpG}$ islands in the human genome, with many found in the promoter region of some genes, generally from upstream of the transcription start site to within the first exon (Gardiner-Garden and Frommer, 1987). DNA methylation in promoter regions is associated with decreased gene expression (Alikhani-Koopaei et al, 2004; Andria and Simon, 1999; Douet et al, 2007; IguchiAriga and Schaffner, 1989; Jaenisch and Bird, 2003; Michelotti et al, 2007). Many transcription factor-binding

*Correspondence: Dr DA Nielsen, Laboratory of the Biology of the Addictive Diseases, The Rockefeller University, Box 171, 1230 York Avenue, New York, NY 10065, USA, Tel: + I 212327 8234, Fax: + I 212327 8574, E-mail: nielsen@rockefeller.edu

Received 9 April 2008; revised 23 May 2008; accepted I6 June 2008 sites, such as those for Sp1, have CpG dinucleotides, and when these are methylated, they display altered binding to their cognate transcription factors (Alikhani-Koopaei et al, 2004; Douet et al, 2007; Michelotti et al, 2007).

Methylation has been shown to be altered by drugs of abuse. In humans, overall DNA methylation was higher in genomic DNA from lymphocytes of alcoholics than from controls (Bleich et al, 2006; Bonsch et al, 2004), with a concomitant decrease in the expression of the DNA methyltransferases DNMT-3a and DNMT-3b (Bonsch et al, 2006). This same group reported increased DNA methylation in the promoter region of the homocysteineinduced endoplasmic reticulum protein gene HERP (Bleich et al, 2006) and the $\alpha$-synuclein gene SNCA in alcoholics (Bonsch et al, 2005). In human lymphoblast cell lines, average overall DNA methylation at the monoamine oxidase a gene promoter was found to be significantly associated point-wise, but not overall experiment-wise, with alcohol dependence and nicotine dependence in women, but not in men (Philibert et al, 2008). Methylation levels at $11 \mathrm{CpG}$ sites were also associated point-wise, but not experiment-wise, with nicotine symptom counts. In cultured mouse cortical neurons, chronic ethanol was reported to induce demethylation of $\mathrm{CpG}$ islands of the NMDA receptor subunit gene $n r 2 b$ with a concomitant increase in $n r 2 b$ expression (Marutha Ravindran and Ticku, 2005). Methylation of the protein phosphatase 1 gene $p p 1$ and demethylation of the reelin gene reln (encoding a protein necessary for neuronal cell signaling) in the mouse 
hippocampus were reported to change after $1 \mathrm{~h}$ in response to fear conditioning (Miller and Sweatt, 2007). Expression of cFos, bdnf, and cdk5 is increased by cocaine; a single cocaine injection was reported to cause chromatin remodeling at the cFos promoter in rat striatum, and at the $b d n f$, and $c d k 5$ promoters after chronic cocaine administration (Kumar et al, 2005). Murine studies suggest that remodeling by chronic cocaine administration was through a decrease in the histone deacetylase HDAC5 function (Renthal et al, 2007). In rats, cocaine administration produced decreased histone methylation in the prefrontal cortex (Black et al, 2006). Maternal cocaine administration in rats increased methylation at a $\mathrm{CpG}$ site in the promoter of the protein kinase $\mathrm{C} \varepsilon(P K C \varepsilon)$ gene in fetal heart, and decreased $P K C \varepsilon$ mRNA and protein levels, presumably through a decrease in Ap1 transcription factor binding (Zhang et al, 2007). DNA methylation of the glucocorticoid receptor promoter in rats was shown to be altered in offspring by maternal behavior (Weaver et al, 2004). In humans, the RELN promoter was found to be hypermethylated, with reduced expression in the brains of schizophrenic patients (Abdolmaleky et al, 2005; Grayson et al, 2005). Mutations in the transcriptional repressor $\mathrm{MeCP} 2$, which binds methylated CpG dinucleotides, cause neuropsychiatric abnormalities including Rett syndrome (Chahrour and Zoghbi, 2007).

The $\mu$-opioid receptor is the site of action of $\beta$-endorphin, morphine, and methadone (Kreek et al, 2005). A common variant in the OPRM1 gene, A118G, encodes an asparagine to aspartic acid substitution. This variant was associated with vulnerability to develop heroin addiction (Bart et al, 2004), and was shown to alter the function of the hypothalamic-pituitary-adrenal axis (reviewed in Kreek, 2006 and Kreek et al, 2005).

Herein, we have examined the methylation levels of 16 $\mathrm{CpG}$ sites in the OPRM1 promoter region in former severe heroin addicts in methadone maintenance pharmacotherapy and in controls. We know of no other study in humans that has reported a significant association, after correcting for multiple testing, of DNA methylation level at a specific $\mathrm{CpG}$ site in any gene with any addiction.

\section{MATERIALS AND METHODS}

\section{Subjects and Phenotyping}

Our sample consisted of 194 former severe heroin addicts and 135 control subjects $(N=329)$, all of Caucasian ethnicity, drawn from consecutive volunteers (January 1995-June 2007) in genetic studies conducted by the Laboratory of the Biology of Addictive Diseases at The Rockefeller University who met the inclusion criteria defined below (Table 1). Subjects were recruited from clinical resources in New York City, and from referrals, newspaper advertisements, and posted notices. All subjects gave specific consent for genetic studies and signed an informed consent approved by The Rockefeller University Hospital Institutional Review Board. Ethnicity was based on the ethnic/cultural background of the subjects, their parents, grandparents, and great-grandparents.

The Addiction Severity Index (ASI; McLellan et al, 1980) was administered and urine analyses were performed for multiple drugs of abuse on all subjects. Former severe heroin addicts $(N=194)$ were long-term heroin addicts who met Federal guidelines for methadone maintenance treatment (1 year or more of daily multiple injections of heroin or other opiates) (Rettig and Yarmolinsky, 1995). Subjects in the control group $(N=135)$ had (1) no illicit drug use for more than 6 months (except cannabis), (2) no excessive use of cannabis (three or more times per week for more than 4 years), (3) no previous history of alcohol drinking to intoxication (three or more times per week for 6 months or more), and (4) no alcohol intoxication or illicit drug use (except cannabis) in the last 30 days.

\section{Isolation of Lymphocyte DNA}

DNA was extracted from peripheral blood lymphocytes using a salting out procedure or from whole blood using the Gentra Puregene kit (Qiagen GmbH, Hilden, Germany) according to the manufacturer's protocol.

\section{Determination of Percent Methylated Cytosine}

Genomic DNA (300 ng) was treated with sodium bisulfite using the EZ-96 DNA Methylation Kit D5004 (Zymo Research, Orange, CA) according to the manufacturer's protocol. The final bisulfite-treated DNA was eluted in $40 \mu \mathrm{l}$ M-Elution Buffer.

Primers for amplifying the upstream OPRM1 CpG island using bisulfite-treated DNA were designed using Methyl Primer Express v1.0 (Applied Biosystems, Foster City, CA) and Vector NTI Advance 10 (Invitrogen, Carlsbad, CA). Amplification was performed with $1 \mu$ l bisulfite-treated DNA, $1 \mu \mathrm{M}$ of each primer (primer A: 5'-TTTTTTTTTGTTT

Table I Sample Categorization

\begin{tabular}{|c|c|c|c|c|c|c|}
\hline \multirow{2}{*}{ Classification } & \multicolumn{3}{|c|}{ Starting sample } & \multicolumn{3}{|c|}{ Samples for analysis of CpG methylation } \\
\hline & Male & Female & Total & Male & Female & Total \\
\hline Controls & 66 & 69 & 135 & 50 & 53 & 103 \\
\hline Total & 183 & 146 & 329 & 149 & 121 & 270 \\
\hline
\end{tabular}

Abbreviation: CpG, cytosine:guanine.

Samples for analysis of CPG methylation are those that had sequencing/ESME analysis carried out in both directions and had a correlation between these analyses $\geqslant 0.7$. 
TAGTTAGG- $3^{\prime}$ and primer B: $5^{\prime}$-CAAATTACCATCTAAAT AAA-3'), $250 \mu \mathrm{M}$ each of dATP, dCTP, dGTP, and TTP, $50 \mathrm{mM} \mathrm{KCl}, 4 \mathrm{mM} \mathrm{MgCl}$, $0.625 \mathrm{U}$ AmpliTaq Gold (Applied Biosystems), and $10 \mathrm{mM}$ Tris- $\mathrm{HCl}(\mathrm{pH} 8.3)$ in $50 \mu \mathrm{l}$. Amplification consisted of $5 \mathrm{~min}$ at $95^{\circ} \mathrm{C}, 40$ cycles of $15 \mathrm{~s}$ at $95^{\circ} \mathrm{C}, 15 \mathrm{~s}$ at $52^{\circ} \mathrm{C}$, and $30 \mathrm{~s}$ at $72^{\circ} \mathrm{C}$, followed by a final elongation step at $72^{\circ} \mathrm{C}$ for $7 \mathrm{~min}$. A second round of amplification was performed as above using $1 \mu \mathrm{l}$ of the product of the first amplification using the nested primers $\mathrm{C}$ : 5'-TGTAAGAAATAGTAGGAGTTGTGGTAG-3' and D: 5'-AA TAAAACAAATTAACCCAAAAACC- $3^{\prime}$. Amplification consisted of $5 \mathrm{~min}$ at $95^{\circ} \mathrm{C}, 40$ cycles of $15 \mathrm{~s}$ at $95^{\circ} \mathrm{C}, 15 \mathrm{~s}$ at $58^{\circ} \mathrm{C}$, and $30 \mathrm{~s}$ at $72^{\circ} \mathrm{C}$, followed by a final elongation step at $72^{\circ} \mathrm{C}$ for $7 \mathrm{~min}$.

\section{Cloning of PCR Fragments}

Amplified DNA fragments, $229 \mathrm{bp}$ in size, were cloned using the TA Cloning Kit into the pCRII plasmid (Invitrogen). DNA from isolated clones was sequenced in both directions using M13 forward and reverse primers and the Big Dye Terminator Cycle Sequencing Kit (Applied Biosystems). Samples were run on an ABI Prism 3700 capillary sequencer (Applied Biosystems).

\section{Direct Sequencing}

Unincorporated nucleotides and primers were treated by mixing $4 \mu \mathrm{l}$ of the final PCR reaction mixture with $1 \mu \mathrm{l}$ ExoSAP-IT (USB Corp., Cleveland, $\mathrm{OH}$ ) followed by incubation at $37^{\circ} \mathrm{C}$ for $30 \mathrm{~min}$ and $80^{\circ} \mathrm{C}$ for $15 \mathrm{~min}$. For sequencing, $1 \mu \mathrm{l}$ ExoSAP-IT-treated DNA was added to $11 \mu \mathrm{l}$ $8 \mathrm{pM}$ primer C or D. Sequencing was performed at Genewiz, Inc. (South Plainfield, NJ) on an ABI $3730 \mathrm{XL}$ sequencer using the ABI 3730POP7SR basecaller (Applied Biosystems).

\section{Epigenetic Sequencing Methylation Analysis Software}

Trace files (.ab1) were analyzed using the Epigenetic Sequencing Methylation Analysis (ESME) version 3.2.1 software from Epigenomics AG (Berlin, Germany) (Lewin et al, 2004). The ESME software was run on a virtual machine (VMware player running on Windows XP) running Red Hat Enterprise Linux 4. The percent methylation calls by the ESME were reviewed by two independent researchers who visually inspected all the methylation calls using the associated electropherograms generated by the ESME software.

\section{Sequence Analysis}

The amplified region of OPRM1 was analyzed for predicted transcription factor-binding sites using Transcription Element Search System (TESS; Schug and Overton, 1977).

\section{Statistical Analysis}

For each sample, for which a forward and reverse sequence file was obtained $(N=304)$, a correlation value was calculated between the arcsine of methylation frequency in the forward and reverse directions. Samples with a correlation $\geqslant 0.7(N=270)$ were included in the analysis of percent methylation at each CpG site (Table 1).
To determine if the mean level of methylation at each CpG dinucleotide site differed between case and control subjects, two different tests were performed. First, the mean of the forward and reverse values was calculated for each CpG site for each sample. A $t$-test was performed using these mean values to examine differences between case and control groups at each $\mathrm{CpG}$ site. Since there were two measurements for each individual, logistic regression using generalized estimating equations (GEE), which accounts for the correlation between the forward and reverse measurements, was also performed (Halekoh and Hojsgaard, 2006). Both these tests were two tailed.

Individual results were first evaluated for point-wise significance $(p<0.05)$. To correct for multiple testing issues, we then computed the false discovery rate (FDR) for each of the $p$-values (Benjamini and Hochberg, 1995).

\section{RESULTS}

We determined the methylation state of a CpG island in the promoter of the OPRM1 gene in 194 former severe heroin addicts stabilized in methadone maintenance treatment and 135 controls. Two CpG islands are found from 400 nucleotides upstream to 1000 nucleotides downstream of the transcription start site (Figure 1). The first CpG island, which we studied, is located from nucleotides -93 to 27 (relative to the A of the ATG translation start site). We examined $16 \mathrm{CpG}$ dinucleotides located at nucleotide -93 , $-90,-80,-71,-60,-50,-32,-25,-18,-14,-10,+12$, $+23,+27,+53$, and +84 of the OPRM1 gene. The CpG dinucleotides -18 and -14 are located in one potential Sp1binding site, the $+12 \mathrm{CpG}$ site in a second binding site, and the $+84 \mathrm{CpG}$ dinucleotide in a third.

\section{Comparison of Results Obtained with Two Methods}

Two methods were employed to determine cytosine methylation at the $\mathrm{CpG}$ dinucleotides. In both methods, DNA is treated with bisulfite to convert unmethylated cytosines to uracil, leaving methylated cytosines unmodified. The region containing the first $\mathrm{CPG}$ island was PCR amplified, and a second round of amplification was performed using nested primers. The first method employs cloning the amplified fragments, isolating individual clones, and sequencing the amplified inserts. The second method employs direct sequencing of the amplified fragment. Trace files are processed using the ESME software (Lewin et al, 2004), which corrects trace files for quality problems, incomplete conversion, imbalanced or overscaled signals, and basecaller artifacts to provide quantitative measurement of cytosine methylation.

\section{The ESME Direct Sequence Analysis Method is Correlated with Clonal Analysis}

Five DNA samples chosen at random from cases and five from controls were analyzed using the cloning method. The methylation pattern of each is shown in Figure 2a. We also analyzed, with this method, five selected samples of cases previously evaluated by sequencing/ESME analysis (Figure 2b). One had the highest percent methylation at the $-25 \mathrm{CpG}$ site (1, Figure 2b), two had the highest 


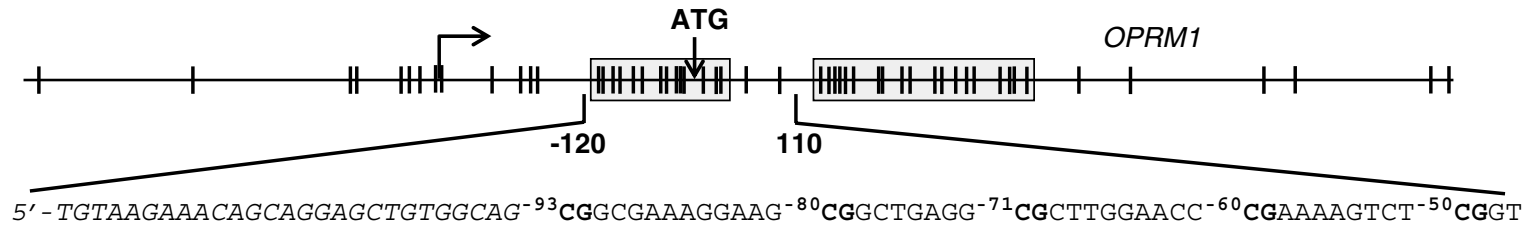

$$
\begin{aligned}
& \text { GCTCCTGGCTACCT }{ }^{-32} \mathrm{CGCACAG}^{-25} \mathrm{CGGTGCC}^{-18} \mathrm{CGCC}^{-14} \mathrm{CGG} \mathrm{C}^{-10}{\mathrm{CGTCAGTACCATGGACAGCA} \mathrm{G}{ }^{12} \mathrm{CGCTGCCCCOA}}^{23} \mathrm{CGAA}{ }^{27} \mathrm{CG} \\
& \text { CCAGCAATTGCACTGATGCCTTGG }{ }^{53} \text { CGTACTCAAGTTGCTCCCCAGCACCCAGCCC }{ }^{84} \text { C GGTTCCTGGGTCAACTTGTCCCACTT-3 ' }
\end{aligned}
$$

Figure I The OPRMI promoter region. Schematic of the OPRMI gene promoter region (from 400 nucleotides upstream to I000 nucleotides downstream of the transcription start site) is presented in the upper diagram. The two CpG islands are boxed. The CpG dinucleotides are indicated as $\mid$ The major transcription start site $(\longrightarrow$ ) is located at -253 upstream of the ATG translation start site. The sequence of the amplified CpG island is displayed below with the sequences corresponding to the nested PCR primers in italics. The $16 \mathrm{CpG}$ sites analyzed for cytosine methylation (bold) with their position relative to the A (chr6: I54 402 373; NCBI Build 36. I, March 2006) of the ATG translation start site (underlined) are indicated. The three putative Sp I transcription factor-binding sites are boxed.

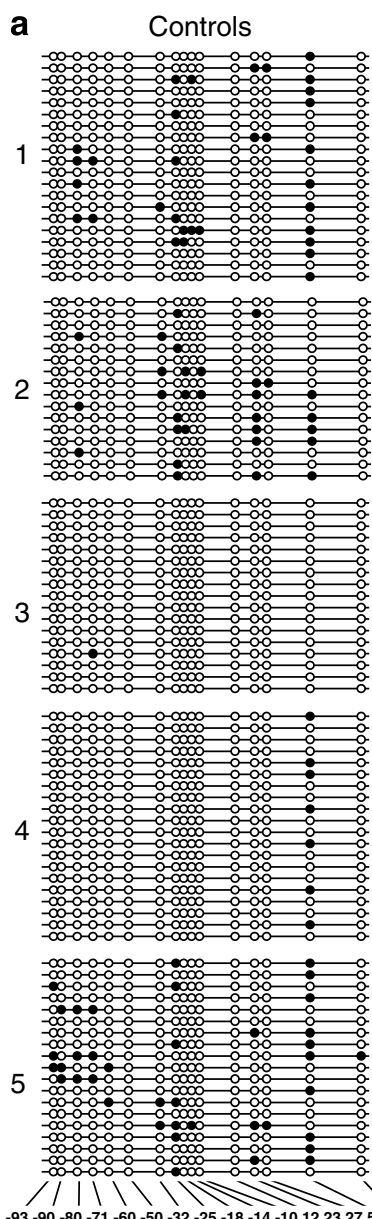

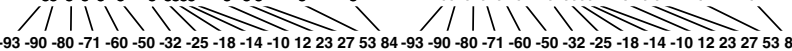
CpG site

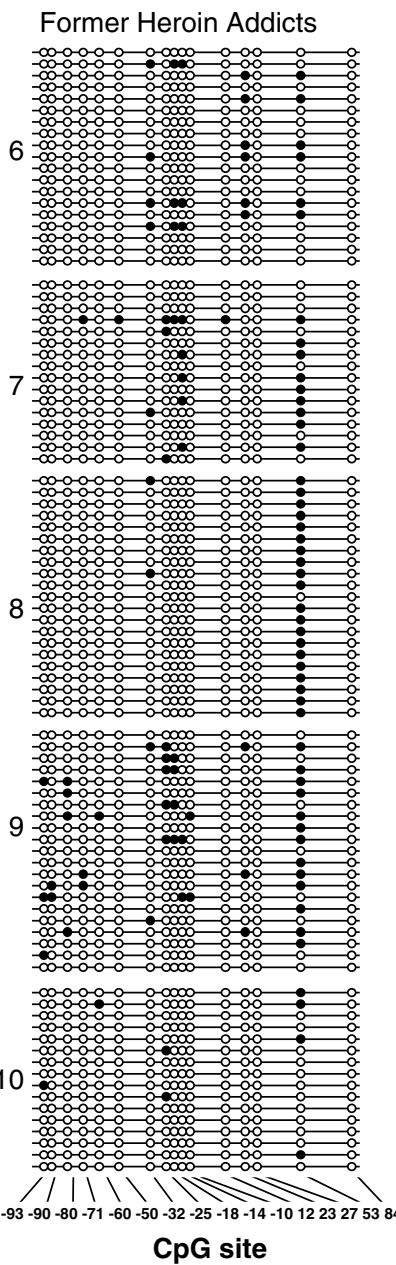

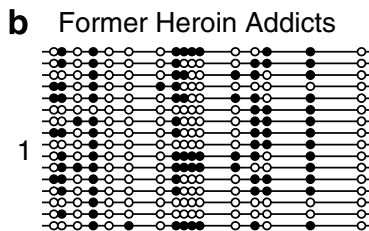
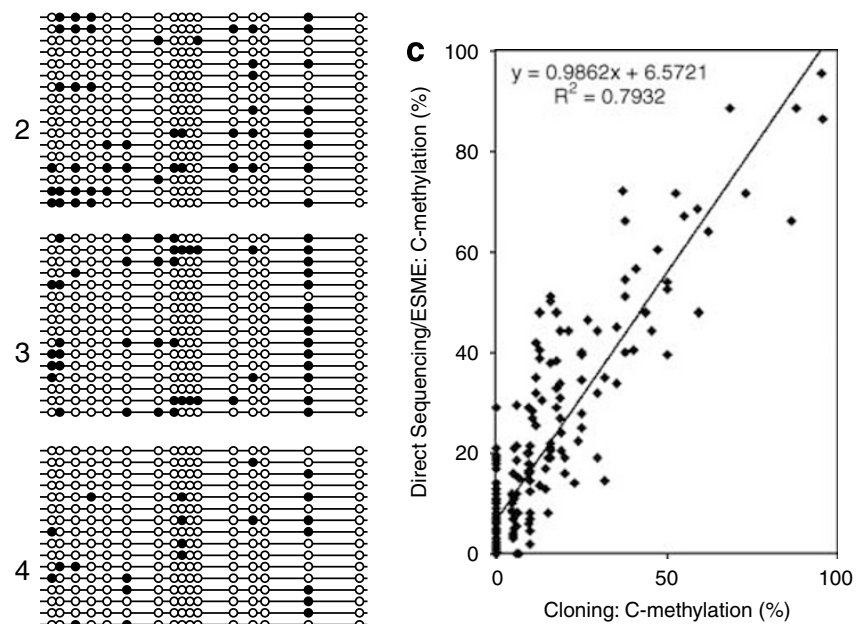

Figure 2 Methylation at the $16 \mathrm{CpG}$ sites. (a) Analysis of cloned amplified bisulfite-treated DNA from five randomly selected controls and five randomly selected former heroin addicts. Solid circles are methylated CPG sites. The location of these sites is shown relative to their location in the amplified OPRM I region. (b) Analysis of cloned bisulfite-treated DNA from five former heroin addicts selected for varying levels of methylation. (c) Correlation of percent cytosine methylation determined by sequencing/ESME (ordinate) and by cloning (abscissa). The correlation is derived from data using clones I, 2, 4, and 6-10 of (a), and $1-3$ and 5 of (b), as these samples had a forward to reverse correlation $\geqslant 0.7$ by sequencing/ESME analysis.

methylation at the $+84 \mathrm{CpG}$ site $(2$ and 3$)$, one had intermediate levels of methylation across the CpG sites (4), and the final sample (5) had low levels of methylation across the sites. All 15 samples were analyzed by sequencing/ESME analysis. Twelve samples had a forward to reverse correlation $\geqslant 0.7$; for these, the correlation of the percentage of methylation was $R^{2}=0.79$ (Figure 2c). 


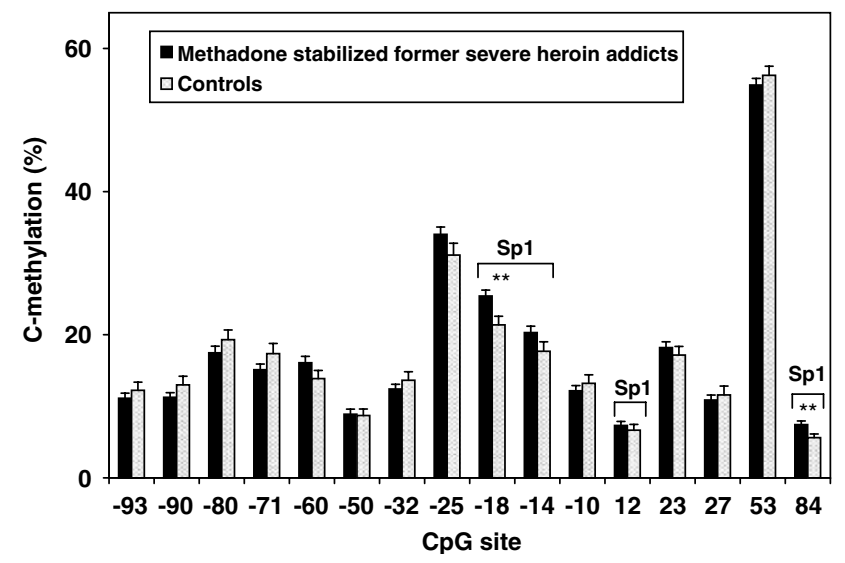

Figure 3 Percent methylation of $16 \mathrm{CpG}$ dinucleotides in the OPRM I promoter region in former severe heroin addicts and controls. CpG sites in SpI binding sites are indicated. $* * 0<0.01$. Error bars represent SEM.

\section{Former Severe Heroin Addicts have Significant Differences in CpG Methylation than Controls}

A total of 167 case and 106 control samples, with a correlation of $\geqslant 0.7$ between the forward and reverse analyses, were analyzed further (Table 1). Methadonestabilized former heroin addicts were found to have significantly higher methylation than controls at two CpG sites (Figure 3). At the $-18 \mathrm{CpG}$ site, the level of methylation was $25.4 \%$ in cases and $21.4 \%$ in controls $(p=0.0035$, GEE; $p=0.0077, t$-test $)$. At the $+84 \mathrm{CpG}$ site the level of methylation was $7.43 \%$ in cases and $5.62 \%$ in controls $(p=0.0095, \mathrm{GEE} ; p=0.0067, t$-test). The difference in methylation at the $-18 \mathrm{CpG}$ site was significant experiment-wise when evaluated by FDR (0.048), but was only point-wise significant for the $+84 \mathrm{CpG}$ site $(0.080)$ (Benjamini and Hochberg, 1995).

\section{DISCUSSION}

This study demonstrates hypermethylation of two $\mathrm{CpG}$ dinucleotide sites in the OPRM1 promoter region in former heroin addicts. Hypermethylation of the -18 and the +204 CpG sites in the former heroin addicts is likely to reduce $O P R M 1$ gene expression since DNA hypermethylation has been shown in other studies to reduce gene expression. When hypermethylated, transcription factor-binding sites have reduced binding affinity for their cognate transcription factors. Since both the -18 and the $+204 \mathrm{CpG}$ sites are in potential Sp1 binding sites, the hypermethylation may decrease binding and transactivation by Spl. The effect of the hypermethylation at the -18 and $+204 \mathrm{CpG}$ sites in the $O P R M 1$ promoter region on transcription binding should be evaluated in future studies.

DNA hypermethylation of specific $\mathrm{CpG}$ sites in the $O P R M 1$ promoter region found in former heroin addicts could be the result of several independent, but by no means exclusive, mechanisms. Increased DNA methylation could be a predisposing factor for vulnerability to develop heroin addiction. Such a methylation state might be inherited through genomic imprinting. Hypermethylation also may be a result of life events occurring before trying heroin.
Finally, chronic heroin use or long-term methadone pharmacotherapy may modulate DNA methylation. Longterm heroin addiction, with its repeated cycles of on/off effects due to heroin's short half-life, may downregulate OPRM1 expression through a negative feedback mechanism involving DNA methylation. Conversely, the relatively constant level of $\mu$-opioid receptor ligand perfusion resulting from long-acting pharmacokinetics of methadone may increase DNA methylation. Studies of heroin addicts at entrance into methadone pharmacotherapy, and when well stabilized, should resolve this issue.

In rats, morphine withdrawal was shown to increase oprm1 expression in the hypothalamus and striatum (Zhou et al, 2006). Acute and subacute cocaine administration increases oprm1 expression in specific brain regions (Azaryan et al, 1998; Yuferov et al, 1999). Also, chronic binge cocaine administration was reported to increase $\mu$-opioid receptor density in specific brain regions (Unterwald et al, 1994), and steady-state methadone administration was shown to prevent cocaine-induced conditioned place preference and to attenuate the increase of OPRM1 mRNA in the nucleus accumbens during cocaine withdrawal (Leri et al, 2006). Further, in rats, the increase in $\mu$-opioid receptor density is reported to persist for over 2 weeks following cessation of cocaine administration (Bailey et al, 2005 ), and in humans, $\mu$-opioid receptor binding potential is increased compared to controls during cocaine abstinence (Gorelick et al, 2005). These effects may explain the efficacy of methadone maintenance treatment for cocaine as well as for heroin addiction (Peles et al, 2006). A possible mechanism of methadone pharmacotherapy is to downregulate the increased OPRM1 expression during heroin withdrawal, thus contributing to the reestablishment of normal $\mu$-opioid receptor levels.

The role of methylation of the OPRM1 gene promoter has been studied by Simon in human cell lines (Andria and Simon, 1999). SH-SY5Y cells, a neural-derived cell line expressing OPRM1, had low basal OPRM1 promoter methylation. In contrast, two other neural-derived cells lines (IMR-32 and nMB cells), which do not naturally express OPRM1, had high methylation of the OPRM1 promoter. Non-OPRM1 expressing, non-neuronally derived cell lines (HEK 293, HepG2, and FS-4) had intermediate methylation. Furthermore, transient transfection experiments indicated that methylation might be involved in OPRM1 expression (Andria and Simon, 1999). It will be of interest, in future studies, to examine the correlation of the level of OPRM1 expression in the lymphocytes with methylation of $\mathrm{CpG}$ sites in the promoter region. In addition, studies should be conducted on the role of Sp1 in the regulation of transcription of unmethylated $v s$ methylated OPRM1 genes.

Peripheral lymphocytes, the source of genomic DNA in this study, express the OPRM1 gene (McCarthy et al, 2001), and their availability greatly expands possible human studies. However, it is not known if these cells have a similar OPRM1 methylation pattern to that in specific brain regions.

The identification of DNA methylation in heroin addiction could lead to novel pharmacotherapies for the treatment of opiate addiction. There are several pharmacological agents, such as azacitidine and valproic acid, that 
could be explored in future preclinical studies on heroin and methadone effects. Azacitidine, a pyrimidine nucleoside analogue of cytidine, when metabolized and incorporated into DNA, acts as an irreversible inhibitor of DNA methyltransferases, preventing DNA methylation, with antineoplastic activity and is thought to activate tumor suppressor genes silenced by hypermethylation. Azacitidine is approved for the treatment of several subtypes of myelodysplastic syndrome, a group of diseases characterized by a disruption in the production of blood cells (Issa and Kantarjian, 2005). Valproic acid, an anticonvulsant, is a histone deacetylase inhibitor (Phiel et al, 2001), and histone acetylation and DNA methylation have been shown to be coupled. Valproic acid is used in the treatment of bipolar disorder and the prevention of migraine headaches. Both azacitidine and valproic acid are currently in clinical trials of the National Cancer Institute.

This is the first study to demonstrate an experiment-wise significant difference in DNA methylation at a specific CpG dinucleotide site between subjects with an addiction and controls at any gene. The identification of DNA methylation as a potential mechanism contributing to the development of heroin addiction, or as a result of heroin use or methadone pharmacotherapy, should lead to improved prevention or treatment of heroin addiction. Elucidation of the factors controlling DNA methylation may also help in understanding the role of the environment in this disease and its treatment.

\section{ACKNOWLEDGEMENTS}

We thank E Ducat, B Ray, D Melia, L Borg, K Bell, $\mathrm{P}$ McHugh, J Schluger, and $\mathrm{H}$ Hofflich for recruiting, screening, and assessment of study subjects, and M Randesi for sequencing assistance. We also thank $\mathrm{CD}$ Allis for his helpful advice before the start of this project and in the review of this paper, to $M$ Rouault for assistance, and to $O$ Levran for critical review of this paper. This study was supported by National Institutes of Health (NIH) grants R03-DA022266 (DN), K05-DA000049 (MJK), P60-DA005130 (MJK), R01-MH79880 (MJK), RR UL1RR024143 (BC), NIHMH R01-44292 (JO), and NSFC grants 30730057 and 30700442 from the Chinese Government (JO).

\section{DISCLOSURE/CONFLICT OF INTEREST}

All the authors, except JO, declare that, except for the income received from our primary employers, no financial support or compensation has been received from any individual or corporate entity over the past 3 years for research or professional service and there are no personal financial holdings that could be perceived as constituting a potential conflict of interests. One author, JO, declares that he personally receives book royalties from the Johns Hopkins University Press and that his laboratory receives funding from Hoffmann-La Roche Inc.

\section{REFERENCES}

Abdolmaleky HM, Cheng KH, Russo A, Smith CL, Faraone SV, Wilcox M et al (2005). Hypermethylation of the reelin (RELN) promoter in the brain of schizophrenic patients: a preliminary report. Am J Med Genet B Neuropsychiatr Genet 134B: 60-66.

Alikhani-Koopaei R, Fouladkou F, Frey FJ, Frey BM (2004). Epigenetic regulation of 11 beta-hydroxysteroid dehydrogenase type 2 expression. J Clin Invest 114: 1146-1157.

Andria ML, Simon EJ (1999). Localization of promoter elements in the human mu-opioid receptor gene and regulation by DNA methylation. Brain Res Mol Brain Res 70: 54-65.

Antequera F, Bird A (1993). Number of CpG islands and genes in human and mouse. Proc Natl Acad Sci USA 90: 11995-11999.

Azaryan AV, Clock BJ, Rosenberger JG, Cox BM (1998). Transient upregulation of mu opioid receptor mRNA levels in nucleus accumbens during chronic cocaine administration. Can J Physiol Pharmacol 76: 278-283.

Bailey A, Gianotti R, Ho A, Kreek MJ (2005). Persistent upregulation of mu-opioid, but not adenosine, receptors in brains of long-term withdrawn escalating dose 'binge' cocainetreated rats. Synapse 57: 160-166.

Bart G, Heilig M, LaForge KS, Pollak L, Leal SM, Ott J et al (2004). Substantial attributable risk related to a functional mu-opioid receptor gene polymorphism in association with heroin addiction in central Sweden. Mol Psychiatry 9: 547-549.

Benjamini Y, Hochberg Y (1995). Controlling the false discovery rate: a practical and powerful approach to multiple testing. J Roy Stat Soc Ser B 57: 289-300.

Black YD, Maclaren FR, Naydenov AV, Carlezon Jr WA, Baxter MG, Konradi C (2006). Altered attention and prefrontal cortex gene expression in rats after binge-like exposure to cocaine during adolescence. J Neurosci 26: 9656-9665.

Bleich S, Lenz B, Ziegenbein M, Beutler S, Frieling H, Kornhuber J et al (2006). Epigenetic DNA hypermethylation of the HERP gene promoter induces down-regulation of its mRNA expression in patients with alcohol dependence. Alcohol Clin Exp Res 30: 587-591.

Bonsch D, Lenz B, Fiszer R, Frieling H, Kornhuber J, Bleich S (2006). Lowered DNA methyltransferase (DNMT-3b) mRNA expression is associated with genomic DNA hypermethylation in patients with chronic alcoholism. J Neural Transm 113: 1299-1304.

Bonsch D, Lenz B, Kornhuber J, Bleich S (2005). DNA hypermethylation of the alpha synuclein promoter in patients with alcoholism. Neuroreport 16: 167-170.

Bonsch D, Lenz B, Reulbach U, Kornhuber J, Bleich S (2004). Homocysteine associated genomic DNA hypermethylation in patients with chronic alcoholism. J Neural Transm 111: 1611-1616.

Chahrour M, Zoghbi HY (2007). The story of Rett syndrome: from clinic to neurobiology. Neuron 56: 422-437.

Douet V, Heller MB, Le Saux O (2007). DNA methylation and Sp1 binding determine the tissue-specific transcriptional activity of the mouse Abcc6 promoter. Biochem Biophys Res Commun 354: 66-71.

Gardiner-Garden M, Frommer M (1987). CpG islands in vertebrate genomes. J Mol Biol 196: 261-282.

Gorelick DA, Kim YK, Bencherif B, Boyd SJ, Nelson R, Copersino $\mathrm{M}$ et al (2005). Imaging brain mu-opioid receptors in abstinent cocaine users: time course and relation to cocaine craving. Biol Psychiatry 57: 1573-1582.

Grayson DR, Jia X, Chen Y, Sharma RP, Mitchell CP, Guidotti A et al (2005). Reelin promoter hypermethylation in schizophrenia. Proc Natl Acad Sci USA 102: 9341-9346.

Halekoh U, Hojsgaard S (2006). The R package geepack for generalized estimating equations. J Stat Software 15: 1-11.

Iguchi-Ariga SM, Schaffner W (1989). CpG methylation of the cAMP-responsive enhancer/promoter sequence TGACGTCA abolishes specific factor binding as well as transcriptional activation. Genes Dev 3: 612-619. 
Issa JP, Kantarjian H (2005). Azacitidine. Nat Rev Drug Discov Suppl: S6-S7.

Jaenisch R, Bird A (2003). Epigenetic regulation of gene expression: how the genome integrates intrinsic and environmental signals. Nat Genet 33: 245-254.

Kreek MJ (2006). Endorphins, gene polymorphisms, stress responsivity, and special addictions: selected topics. In: Madras BK, Colvis CM, Pollock JD, Rutter JL, Shurtleff D, von Zastrow M (eds). Cell Biology of Addiction. Cold Spring Harbor Laboratory Press: Cold Spring Harbor. pp 63-92.

Kreek MJ, Bart G, Lilly C, LaForge KS, Nielsen DA (2005). Pharmacogenetics and human molecular genetics of opiate and cocaine addictions and their treatments. Pharmacol Rev 57: $1-26$.

Kumar A, Choi KH, Renthal W, Tsankova NM, Theobald DE, Truong HT et al (2005). Chromatin remodeling is a key mechanism underlying cocaine-induced plasticity in striatum. Neuron 48: 303-314.

Leri F, Zhou Y, Goddard B, Cummins E, Kreek MJ (2006). Effects of high-dose methadone maintenance on cocaine place conditioning, cocaine self-administration, and mu-opioid receptor mRNA expression in the rat brain. Neuropsychopharmacology 31: $1462-1474$.

Lewin J, Schmitt AO, Adorjan P, Hildmann T, Piepenbrock C (2004). Quantitative DNA methylation analysis based on fourdye trace data from direct sequencing of PCR amplificates. Bioinformatics 20: 3005-3012.

Marutha Ravindran CR, Ticku MK (2005). Role of CpG islands in the up-regulation of NMDA receptor NR2B gene expression following chronic ethanol treatment of cultured cortical neurons of mice. Neurochem Int 46: 313-327.

McCarthy L, Szabo I, Nitsche JF, Pintar JE, Rogers TJ (2001). Expression of functional mu-opioid receptors during $\mathrm{T}$ cell development. J Neuroimmunol 114: 173-180.

McLellan AT, Luborsky L, Woody GE, O'Brien CP (1980). An improved diagnostic evaluation instrument for substance abuse patients. The Addiction Severity Index. J Nerv Ment Dis 168: 26-33.

Michelotti GA, Brinkley DM, Morris DP, Smith MP, Louie RJ, Schwinn DA (2007). Epigenetic regulation of human alphaldadrenergic receptor gene expression: a role for DNA methylation in Sp1-dependent regulation. FASEB J 21: 1979-1993.
Miller CA, Sweatt JD (2007). Covalent modification of DNA regulates memory formation. Neuron 53: 857-869.

Peles E, Kreek MJ, Kellogg S, Adelson M (2006). High methadone dose significantly reduces cocaine use in methadone maintenance treatment (MMT) patients. $J$ Addict Dis 25: 43-50.

Phiel CJ, Zhang F, Huang EY, Guenther MG, Lazar MA, Klein PS (2001). Histone deacetylase is a direct target of valproic acid, a potent anticonvulsant, mood stabilizer, and teratogen. J Biol Chem 276: 36734-36741.

Philibert RA, Gunter TD, Beach SR, Brody GH, Madan A (2008). MAOA methylation is associated with nicotine and alcohol dependence in women. Am J Med Genet B Neuropsychiatr Genet 147B: $565-570$

Renthal W, Maze I, Krishnan V, Covington III HE, Xiao G, Kumar A et al (2007). Histone deacetylase 5 epigenetically controls behavioral adaptations to chronic emotional stimuli. Neuron 56: 517-529.

Rettig RA, Yarmolinsky A (eds) (1995). Federal Regulation of Methadone Treatment. National Academy Press: Washington, DC.

Schug J, Overton GC (1977). TESS: Transcription Element Search Software on the WWW. Computational Biology and Informatics Laboratory, School of Medicine, University of Pennsylvania: Philadelphia.

Unterwald EM, Rubenfeld JM, Kreek MJ (1994). Repeated cocaine administration upregulates kappa and mu, but not delta, opioid receptors. Neuroreport 5: 1613-1616.

Weaver IC, Cervoni N, Champagne FA, D'Alessio AC, Sharma S, Seckl JR et al (2004). Epigenetic programming by maternal behavior. Nat Neurosci 7: 847-854.

Yuferov V, Zhou Y, Spangler R, Maggos CE, Ho A, Kreek MJ (1999). Acute 'binge' cocaine increases mu-opioid receptor mRNA levels in areas of the rat mesolimbic mesocortical dopamine system. Brain Res Bull 48: 109-112.

Zhang H, Darwanto A, Linkhart TA, Sowers LC, Zhang L (2007). Maternal cocaine administration causes an epigenetic modification of protein kinase Cepsilon gene expression in fetal rat heart. Mol Pharmacol 71: 1319-1328.

Zhou Y, Bendor J, Hofmann L, Randesi M, Ho A, Kreek MJ (2006). $\mathrm{Mu}$ opioid receptor and orexin/hypocretin mRNA levels in the lateral hypothalamus and striatum are enhanced by morphine withdrawal. J Endocrinol 191: 137-145. 